\title{
Rehabilitation Program for Spinal Cord Injury Neurological Level C2 due to Foramen Magnum Meningioma
}

\author{
Soracca Fellicita Sugiarto, Tanti Ajoe Kesoema
}

Department of Physical Medicine and Rehabilitation, Faculty of Medicine, Diponegoro University, Semarang, Indonesia.

\begin{abstract}
Introduction: Foramen magnum meningioma is a rare case. The incidence is $0.3 \%-3.2 \%$ of all meningiomas. Clinical manifestations of foramen magnum meningioma are atypical and unpredictable. The main therapy for foramen magnum meningioma is surgery. The role of rehabilitation becomes important in the process after surgery.

Case Presentation: A 46 years old female had weakness and loss of sensory of her upper and lower limbs, accompanied by urinary retention and constipation in the last 2 month, categorized by ASIA impairment scale (AIS) C neurological level of injury at C2. Cervical MRI with contrast showed the impression of an extramedullary intradural mass as high as the inferior aspect of the pons to the corpus vertebrae cervical 1 supports the picture of meningiomas.

The rehabilitation programs after surgery were active assistive range of motion exercise progressing to active range of motion, neuromuscular electrical stimulation, sensory stimulation and bladder and bowel training.

Conclusion: The patient's expectation for returning to independency is a long-term goal of the rehabilitation program. After definitive therapy (surgery) is conducted, medical rehabilitation management can be done as early as possible to achieve the optimum functional recovery. Muscle strengthening, sensory stimulation and bladder/bowel training improved motor, sensory and autonomic function.
\end{abstract}

Keywords: Foramen magnum meningioma, spinal cord injury, motoric training, sensory stimulation, bladder training, bowel training, functional recovery, case report 


\section{ABSTRAK}

Pendahuluan: Meningioma foramen magnum merupakan kasus yang langka. Insidensi nya $0.3 \%-3.2 \%$ dari semua meningioma. Manifestasi klinis dari Meningioma foramen magnum atipikal dan tidak dapat diprediksi. Terapi utama pada Meningioma foramen magnum adalah pembedahan. Peran rehabilitasi menjadi penting dalam proses setelah pembedahan.

Presentasi Kasus: Seorang wanita berusia 46 tahun mengeluh lemah dan baal pada anggota tubuh bagian atas dan bawahnya, disertai dengan retensi urin dan retensi alvi dalam 2 bulan terakhir, dikategorikan oleh ASIA Impairment Scale (AIS) C level neurologis di C2. MRI cervikal dengan kontras menunjukkan kesan massa intradural ekstramedular setinggi aspek inferior pons ke korpus vertebra cervikal 1 mendukung gambaran meningioma.

Program rehabilitasi setelah operasi adalah latihan lingkup gerak sendi aktif dibantu yang berlanjut menjadi latihan lingkup gerak sendi aktif, stimulasi elektrik neuromuskuler, stimulasi sensorik dan latihan kandung kemih dan bowel.

Kesimpulan: Harapan pasien untuk kembali ke kemandirian adalah tujuan jangka panjang dari program rehabilitasi. Setelah terapi definitif (operasi) dilakukan, manajemen rehabilitasi medis dapat dilakukan sedini mungkin untuk mencapai pemulihan fungsional yang optimal. Penguatan otot, stimulasi sensorik dan pelatihan kandung kemih / usus meningkatkan fungsi motorik, sensorik dan otonom.

Kata Kunci: Meningioma foramen magnum, cedera tulang belakang, latihan motorik, stimulasi sensorik, latihan kandung kemih, latihan bowel, pemulihan fumgsional, laporan kasus

\section{Correspondent Detail:}

\section{Soracca Fellicita Sugiarto}

Email: sfellicitasugiarto@gmail.com

Department of Physical Medicine and

Rehabilitation, Dr. Kariadi General Hospital, Diponegoro University, Semarang, Indonesia

\section{INTRODUCTION}

Foramen magnum meningioma is a rare case, account for $0.3 \%$ to $3.2 \%$ of all meningiomas. ${ }^{1}$ The definition of foramen magnum tumor itself varies in each literature. ${ }^{2}$ Some sources say meningiomas are considered to originate from the foramen magnum if the tumor insertion is in a region whose anterior border is the lower third of the clivus and the upper edge of the $\mathrm{C} 2$ corpus, the lateral border is the jugular tubercles and the superior aspect of lamina $\mathrm{C} 2$ and its posterior border is the anterior part of occipital edge and the spinous process of $\mathrm{C} 2 .^{2,3}$ Clinical manifestations of foramen magnum meningioma are atypical and unpredictable ${ }^{2}$, usually includes lower cranial nerve palsies and signs and symptoms due to spinal cord compression. ${ }^{4}$ Due to the rarity of the disease and its often-insidious onset, patients are often misdiagnosed or develop severe neurological deficits until proper diagnosis and treatment can be established. ${ }^{4}$ 
Spinal cord injury (SCI) arising from spinal tumors are particularly challenging for both patients and healthcare providers owing to the neurological and functional deficits, increased comorbidities due to cancer, and diminished life expectancy. ${ }^{5}$

Patients with cervical and high thoracic SCI are at higher risk for developing complications. The following complications are cardiovascular complications, respiratory complications, neurogenic bladder and bowel, pressure ulcers, spasticity, thromboembolism, and neuromuscular complications. ${ }^{6}$

The main therapy for foramen magnum meningioma is surgery. Radiosurgery or radiotherapy is considered as an alternative in some cases. ${ }^{2}$ Weakness in the limbs, hypesthesia, and other problems may persist after surgery. Other problems such as dysarthria can also occur depending on the location of the tumor. ${ }^{1}$ The role of rehabilitation becomes important in the process after surgery. ${ }^{7}$

The goal of rehabilitation is to restore the loss of function or return to a level as close as possible prior to the injury. ${ }^{7}$ Early intervention by rehabilitation specialists can also prevent complications. Furthermore, prescribing proper wheelchairs are crucial for providing appropriate mobility and preventing complications such as fall, contracture and pressure ulcer. ${ }^{8}$

\section{CASE REPORT}

A 46 years old female was referred to Dr. Kariadi General Hospital from local hospital due to the progressive weakness of all extremities. Patient had tingling sensation on both arms progressing on both legs since a year ago. Patient started to have asymmetric weakness and loss of sensory of her upper and lower limbs in the last 7 months, accompanied by urinary retention and constipation in the last 2 months. Patient has been catheterized for 2 months. Patient has also using laxative. American Spinal Injury Association (ASIA) impairment scale (AIS) has showed neurological level of injury at level C2 with neurogenic bladder and bowel, concluded as AIS C. The patient's skin was dry, she also said that she does not sweat. There were no pressure ulcers. Patient could eat and drink without choking or coughing, she could also breath dependently. Activity of daily living was entirely dependent on others. There was no history of chronic diseases, history of using birth control (3 monthly injection) for more than 20 years, history of radiological exposure is denied. Patient was a snake-fruit farmer, she stopped working due to this illness.

Cervical MRI with contrast showed the impression of an extramedullary intradural mass as high as the inferior aspect of the pons to the corpus vertebrae cervical 1 supports the picture of meningiomas. 


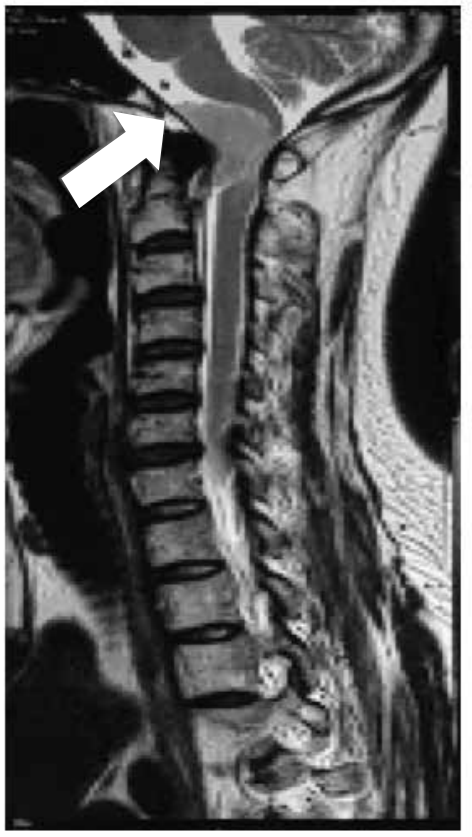

Figure 1. MRI sagittal view segment cervical

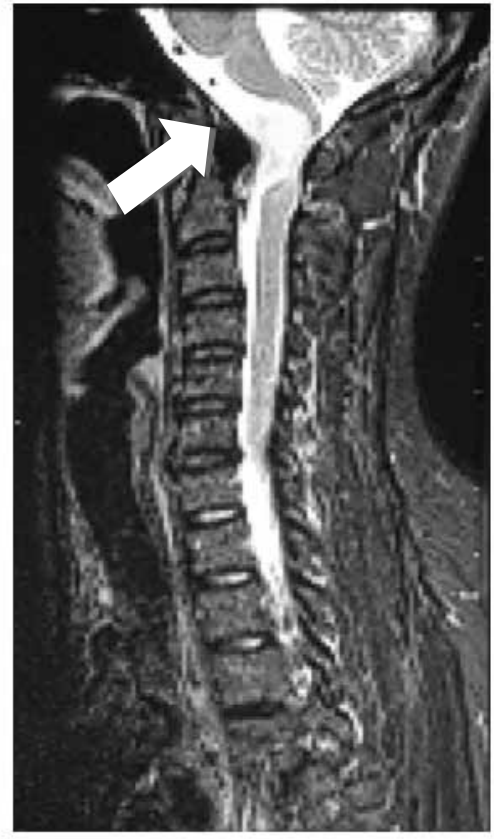

Figure 2. Cervical MRI with contrast

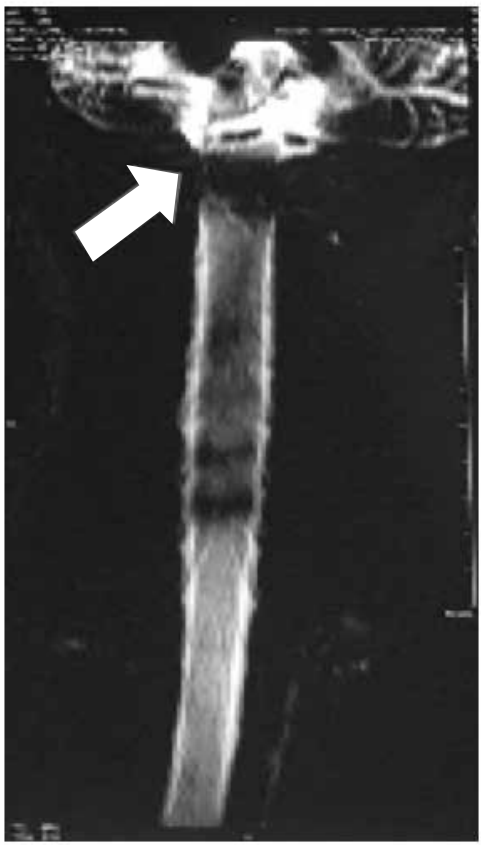

Figure 3. Cervical MRI

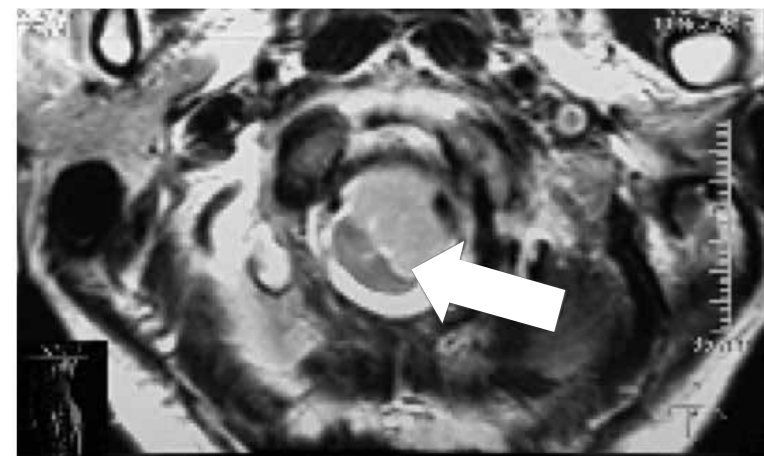

Figure 4. MRI axial view segment cervical

From physical examination, vital signs and internal status are within normal limit. Cranial nerves are all within normal limit. MMT examination of right upper extremity C5: 2, C6: 2, C7: 1, C8: 2, T1: 1. Left upper extremity C5: 2, C6: 2, C7: 1, C8: 1, T1: 1. MMT examination of right lower extremity L2: 1, L3: 1, L4: 1, L5: 2, S1: 1. Left lower extremity L2: 1, L3: 1, L4: 1, L5: 1, S1: 1.
Light touch and pinprick test at C2 right and left side are 2. From C3 until S4-5 are 1 for right and left side. Proprioceptive of upper and lower extremities are still normal. Voluntary Anal Contraction (VAC) and Deep Anal Pressure (DAP) are positive. ACR reflex is positive.

Physiological reflex of biceps and triceps tendon are increase $+3 /+3$, patellar and achilles tendon are also increase $+3 /+3$. Pathological reflex Hoffman and Trommner are all positive in both sides. Babinski is also positive in both feet. Spasticity in all extremities assessed with modified ashworth score 1+. Clonus (+/+). Functional assessment with Spinal Cord Injury Measurement (SCIM) in total is 10.

Patient underwent surgery (skull base craniotomy) and the specimens taken were examined and concluded as atypical meningioma (WHO grade II). 


\section{RESULT}

Patients treated in the ICU after surgery. Medical rehabilitation is done on the first day after surgery at the ICU. Patient experienced respiratory failure and breathed with a ventilator. The rehabilitation programs were passive range of motion exercise progressing to active assistive range of motion exercise and neuromuscular electrical stimulation placed in big muscles such as quadriceps, hamstring, gastrocnemius, biceps, and triceps. Antigravity positioning and tilted every 2 hours to prevent pressure ulcers.

A week after, patient was transferred to the ward. From physical examination, patient was in a good awareness, vital signs and internal status are within normal limit. Cranial nerves are within normal limit. MMT of right upper extremity is C5: 2, C6: 2, C7: 2, C8: 3, T1: 3 and left upper extremity is C5: 2, C6: 2, C7: 2, C8: 2, T1: 3. MMT of right lower extremity is C5: 2, C6: 2, C7: 3, C8: 3, T1: 3 and left lower extremity is C5: 2, C6: 2, C7: 2, C8: 3, T1: 3.

Light touch and pinprick test at $\mathrm{C} 2$ right and left side are 2. From C3 until S4-5 are 1 for right and left side. Voluntary Anal Contraction (VAC) and Deep Anal Pressure (DAP) are positive. ACR reflex is positive.

Physiological reflexes of all extremities are still increase and Pathological reflexes (Babinski) are still positive. Clonus are still found in both feet. The rehabilitation programs progress to active assistive range of motion exercise progressing to active range of motion, sensory stimulation, and bladder and bowel training, and tilted every 2 hours to prevent pressure ulcers.

Patient went home 10 days after surgery with standard manual wheelchair. The rehabilitation programs continued in an outpatient basis such as wheelchair training, weight shifting training, transfer training, bladder and bowel training, also occupational therapy to gain independency in activity daily living.

6 weeks after surgery, MMT examination of upper and lower extremities are increasing. Right upper extremity is C5: 4, C6: 3, C7: 4, C8: 4, T1: 4 and left upper extremity is C5: 4, C6: 3, C7: 4, C8: 4, T1: 4. Right lower extremity is L2: 3, L3: 3, L4: 4, L5: 4, S1: 4 and left lower extremity is C5: 3, C6: 3, C7: 4, C8: 4, T1: 4. Physiological reflex of biceps and triceps tendon are still increase $+3 /+3$, patellar and achilles tendon are still increase $+3 /+3$ as well. Pathological reflex Hoffman and Trommner are all negative in both sides. Babinski is still positive in both feet. Spasticity in all extremities assessed with modified ashworth score is 1 . Clonus is still positive in both feet. Light touch and pinprick test decreased from $\mathrm{C} 3$ and below. Proprioceptive of upper and lower extremities are still normal. Voluntary Anal Contraction (VAC) and Deep Anal Pressure (DAP) are positive. Functional assessment with Spinal Cord Injury Measurement (SCIM) in total is 73 .

\section{DISCUSSION}

Tumors in the foramen magnum region are often difficult to diagnose because of the clinical manifestations that are not typical and varied. ${ }^{4}$ Contrast computed tomography (CT) 
can diagnose $75 \%$ of patients with foramen magnum meningioma. However, MRI is an imaging choice for diagnosing lesions in the foramen magnum. ${ }^{9}$ Although alternative therapies have advanced, surgery is still the treatment of choice in foramen magnum meningioma. ${ }^{2,9}$ From the surgery report it was found that the tumor was removed in total gross (Simpson grade II) with a recurrence presentation of $11-15 \% .{ }^{10}$

Medical rehabilitation in patients with meningioma is conducted before and after surgery. The programs provided depend on functional impairments that occur in patients and aims to restore the patient's ability to perform optimal daily activities and activities in the community. Short-term goals in this patient are maintaining the range of motion of the joints, increasing muscle strength, increasing sensibility, preventing complications such as venous thromboembolism (VTE), pressure ulcers, and increasing mobilization and transfer. Long-term goals are dependent in activities of daily living and able to get back to work.

The highest priorities during acute care are the prevention of medical complications, management of bowel/bladder function and encouragement of early mobilization. ${ }^{11}$

The reported incidence of VTE in post brain tumor surgical group reportedly ranges from $3.0 \%$ to $13.7 \%$. VTE is one of the main reasons for unplanned hospital readmissions in brain tumor patients, rates of readmission for VTE range from $19.7 \%$ to $22 \%$. Patients readmitted to a hospital within 30 days of a craniotomy for reasons that may include VTE had twice the risk of mortality compared with patients who were not readmitted. Immobility and pre-operative motor deficits increase the risk for VTE. Early post-craniotomy mobilization therapies in combination with modalities such as neuromuscular electrical stimulation have been shown to reduce VTE complications. ${ }^{11}$

A rehabilitation program for outpatient depends on the patient's impairments, disabilities and strengths, short and long-term functional goals, and treatment strategies to achieve goals and prevent complications. Rehabilitation programs for this patient consisted of active range of motion exercise of all extremities (twice daily, 8-12 times repetition, 3-5 sets, 30 seconds rest in each sets ${ }^{12}$ ), isometric exercises of upper and lower extremities targeting big muscles group (twice daily, 20 minutes per session $^{12}$ ), sensory stimulation with different textures (twice weekly, 20 minutes per session), bladder and bowel training, wheelchair training targeted wheelchair propulsion on level surfaces $^{13}$, transfer from and to wheelchair ${ }^{13}$, and occupational therapy for independency in activity daily living.

\section{CONCLUSION}

The patient's expectation for returning to independency is a long-term goal of the rehabilitation program. After definitive therapy (surgery) is conducted, medical rehabilitation management can be done as early as possible to achieve the optimum functional recovery. Muscle strengthening, sensory stimulation and bladder/bowel training improved motor, sensory and autonomic function. 


\section{REFERENCES}

1. Hajhouji F, Lmejjati M, Aniba K, Laghmari M, Ghannane H, Benali SA. Foramen magnum meningioma's management: the experience of the department of neurosurgery in Marrakesh. Pan Afr Med J. 2017 Jan 30;26-42.

2. Pamir MN, Ozduman K. Foramen magnum meningioma. In: Meningiomas: A Comprehensive Text. $1^{\text {st }}$ Ed. Philadelphia: Saunders Elsevier; 2010. p.534-57.

3. Richardson AM, Au K, Morcos J. Foramen magnum meningiomas. In: Couldwell W, editors. Skull Base Surgery of the Posterior Fossa. Cham: Springer; 2017. p.135-43.

4. Zogopoulos P, Venetikidis A, Vretakos $\mathrm{G}$, Rologis D. Insidious presentation of a foramen magnum meningioma - a case report. Arc Cas Rep CMed. 2016 May 24;2(1):112.

5. Ge L, Arul K, Mesfin A. Spinal cord injury from spinal tumors: prevalence, management, and outcomes. World Neurosurg. 2018 Nov 1;122:1551-56.

6. Hagen EM. Acute complications of spinal cord injuries. World J Orthop. 2015 Jan 18;6(1):17-23.
7. Garrison SJ. Handbook of physical medicine and rehabilitation. $2^{\text {nd }}$ Ed. Philadelphia: Lippincott Williams and Wilkins; 2003.

8. Campagnolo DI, Kirshblum S. Spinal cord medicine. Chapter 17, Rehabilitation of Spinal cord injury. 2nd Ed. Philadelphia: Lippincott Williams \& Wilkins; 2011. p. 544-95.

9. Borba LAB, Colli BO. Foramen magnum meningiomas. In: Lee J.H., editors. Meningiomas. London: Springer; 2009. p. 449-56.

10. Greenberg MS. Meningioma. Handbook of Neurosurgery. $1^{\text {st }}$ Ed. Germany: Thieme; 2010. p. 613-21.

11. Kushner DS. Principles of neurorehabilitation. In: Weiner WJ, Goerz CG, editors. Neurology for the NonNeurologist. 6th Ed. Philadelphia: Walters Kluwer/Lippincott Williams and Wilkins; 2010. p. 551-71.

12. Riebe, Deborah, Jonathan KE, Gary L, Meir M. Acsm's Guidelines for Exercise Testing and Prescription. $9^{\text {th }}$ Ed. 2014.

13. Oyster ML, Smith IJ, Kirby RL, et al. Wheelchair skill performance of manual wheelchair users with spinal cord injury. Top Spinal Cord Inj Rehabil. 2012;18(2):138-9. 